\title{
Elevated Expression of EPHA2 Is Associated With Poor Prognosis After Radical Prostatectomy in Prostate Cancer
}

\author{
HIROFUMI KUROSE ${ }^{1,2}$, KOSUKE UEDA ${ }^{2}$, REIICHIRO KONDO ${ }^{1}$, SACHIKO OGASAWARA ${ }^{1}$, \\ HIRONORI KUSANO ${ }^{1}$, SAKIKO SANADA ${ }^{1}$, YOSHIKI NAITO ${ }^{1,3}$, MAKOTO NAKIRI $^{2}$, \\ KIYOAKI NISHIHARA ${ }^{2}$, TATSUYUKI KAKUMA ${ }^{4}$, JUN AKIBA ${ }^{3}$, TSUKASA IGAWA ${ }^{2}$ and HIROHISA YANO ${ }^{1}$ \\ ${ }^{1}$ Department of Pathology, Kurume University School of Medicine, Kurume, Japan; \\ ${ }^{2}$ Department of Urology, Kurume University School of Medicine, Kurume, Japan; \\ ${ }^{3}$ Department of Diagnostic Pathology, Kurume University Hospital, Kurume, Japan; \\ ${ }^{4}$ Biostatistics Center, Kurume University School of Medicine, Kurume, Japan
}

\begin{abstract}
Background/Aim: Therapeutic targeting of receptor protein tyrosine kinases (PTKs) has proven successful in treating cancer. However, reports about PTKs in treating prostate cancer are few. Elevated expression of the erythropoietin-producing hepatocellular receptor A2 (EPHA2) receptor tyrosine kinase, a transmembrane protein, is associated with poor prognosis of certain cancer types when the enzyme is dephosphorylated. This study investigated whether EPHA2 is useful in predicting the biochemical recurrence of prostate cancer. Patients and Methods: Data from 241 patients who had undergone total prostatectomy between 2007 and 2011 were used. EPHA2 protein expression was categorized as high or low by two pathologists. The relationship was examined between EPHA2 expression level (high vs. low) and clinicopathological factors including biochemical recurrence. Correlations were examined between EPHA2, low-molecular-weight protein tyrosine phosphatase (LMW-PTP), E-cadherin, and Ki-67. Results: EPHA2 expression was high in 121 (50.2\%) and low in 120 (49.8\%) patients. A log-rank test revealed early biochemical recurrence in the high-expression group. Gleason score, Ki-67 labeling index, and biochemical recurrence were more frequent in the high-expression group. Furthermore, multivariate analyses revealed that high EPHA2 expression was an independent prognostic factor for biochemical recurrence (hazard ratio $=3.62,95 \%$ confidence interval $=2.39-5.61)$. Correlations between EPHA2 and both LMW-PTP and Ki-67 labeling index
\end{abstract}

Correspondence to: Hirofumi Kurose, Department of Pathology, Kurume University School of Medicine, 67 Asahi-machi, Kurume 830-0011, Japan. Tel.: +81 942317546, Fax: +81 942320905, e-mail: kurose_hirofumi@med.kurume-u.ac.jp

Key Words: EPH receptor, LMW-PTP, E-cadherin, biomarker, biochemical recurrence, protein kinase. were positive, whereas EPHA2 and E-cadherin were negatively correlated. Conclusion: EPHA2 overexpression is predictive of aggressive prostate cancer behavior. EPHA2 may be a powerful prognostic biomarker for decision-making in postoperative follow-up after total prostatectomy, and regarding the need for palliative treatment. Additionally, it may be an important therapeutic target.

The increased use of prostate-specific antigen (PSA) screening has led to a growing number of men being diagnosed with organ-confined or locally advanced prostate cancer (PCa). Therefore, when radical prostatectomy is selected to treat localized $\mathrm{PCa}$, the prognosis is generally good (1). However, postoperative biochemical recurrence (BCR) occurs for $16-31 \%$ of patients within 5 years and for $25-53 \%$ within 10 years $(2,3)$. Some of these cases develop into castration-resistant $\mathrm{PCa}$ after clinical recurrence, often leading to poor outcomes. Thus, BCR is often used to justify the application of salvage therapies, such as endocrine therapy and radiotherapy.

$\mathrm{BCR}$ of PCa after prostatectomy has been associated with multiple factors including positive surgical margins (RM1), pre-operative PSA score, Gleason score (GS) at prostatectomy, and pathological staging. Of these, a positive surgical margin is the most important predictive factor for BCR (recurrence rate=1.5- to 6.0-fold higher) (4-12). However, there are few reports of effective biomarkers that can be used to predict BCR.

Protein tyrosine kinases (PTKs) are a diverse group of transmembrane proteins involved in signal transduction pathways; these PTKs control cell shape, proliferation, differentiation and migration (13-15). Recently, therapeutic targeting of PTKs, such as EGFR and HER2/neu, has proven successful for clinical application in cancer treatment (16). However, there are fewer reports about the use of PTKs to treat $\mathrm{PCa}$ than for other carcinomas. 
The EPH receptors are the largest family of PTKs. The erythropoietin-producing hepatocellular receptor A2 (EPHA2) receptor tyrosine kinase, a $130 \mathrm{kDa}$ transmembrane protein, is primarily found in adult human epithelial cells and is located on chromosome 1 p36.1 $(17,18)$. Some studies revealed that EPHA2 was overexpressed in several human cancer types, including PCa (19). Generally, EPHA2 is phosphorylated and found at low levels in nontransformed cells $(20,21)$. In contrast, in malignant cells, EPHA2 is not tyrosine phosphorylated, partly because of the inability to bind to its membrane-anchored ligand as a result of the unstable cell-cell contacts in malignant cells. Recently, we reported that low-molecular-weight protein tyrosine phosphatase (LMW-PTP) has potential as a highly useful prognostic biomarker in PCa (22). LMW-PTP is an important negative regulator of EPHA2 phosphorylation, being involved in the proliferation, invasion, and migration of tumors, through the dephosphorylation of EPHA2 (23-25). In addition, E-cadherin, which serves as a powerful suppressor of metastasis, may also regulate EPHA2 ligand binding (26).

To date, as far as we are aware there have been no reports evaluating the role of EPHA2 expression in $\mathrm{PCa}$, particularly with respect to clinical outcome, nor reporting correlations between EPHA2, LMW-PTP, and E-cadherin in PCa. In this study, we evaluated EPHA2 expression in patients with localized PCa who had undergone prostatectomy in order to investigate whether EPHA2 is useful as a predictive factor for BCR, and whether EPHA2 is correlated with LMW-PTP, E-cadherin and Ki-67 levels in patients with PCa.

\section{Patients and Methods}

Patients and tissue samples. Patients $(\mathrm{n}=241)$ who underwent prostatectomy at Kurume University Hospital (Kurume, Japan) between January 2007 and December 2011 were enrolled in this study. As part of this study, the pathological diagnoses of the patients were re-examined. The following patients were excluded from this study beforehand: Patients who had undergone hormonal therapy or radiotherapy before surgery and patients found to have stage pT0 disease during surgery. All patients were pathologically diagnosed with prostatic adenocarcinoma. Paraffin-embedded samples of primary prostate cancer tissue from 241 patients were used to construct a tissue microarray (TMA). Histopathological evaluations were performed by three pathologists (H.K., R.K., and H.Y.). Pathological diagnosis was performed according to the 2016 World Health Organization Classification of Tumors of the Urinary System and Male Genital Organs (27). This study was approved by the Research Ethics Committee of Kurume University, and conformed to the guidelines of the Declaration of Helsinki (approval number: 18301).

Immunohistochemical analysis. Paraffin-embedded tissue samples were cut to a thickness of $4 \mu \mathrm{m}$, examined on coated slide glass, and labeled with anti-EPHA2 (A-0912401, dilution 1:100; Abnova, Taipei, Taiwan), anti-LMW-PTP (sc-100343, dilution 1:100; Santa Cruz
Biotechnologies, Dallas TX, USA), anti-E-cadherin (NCH-38, dilution 1:100; Dako, Glostrup, Denmark), and anti-Ki-67 (NCL-Ki67-MM1, dilution 1:200; Leica Biosystems, Nussloch, Germany) using a BenchMark ULTRA (Ventana Automated Systems, Inc., Tucson, AZ, USA). Briefly, the slides were heat-treated using Ventana's ULTRA cell conditioning 1 retrieval solution (CC1; Ventana Automated Systems, Inc.) for $36 \mathrm{~min}$ at $95^{\circ} \mathrm{C}$ and were incubated with antibodies for $32 \mathrm{~min}$ at $37^{\circ} \mathrm{C}$. An automated system with a Ventana UltraVIEW 3,3'-diaminobenzidine (DAB) detection kit was used.

We only considered cytoplasmic expression of EPHA2 and LMW-PTP as positive (Figures 1 and 2). E-Cadherin that was stained in the cell membrane was considered as positive (Figure 2). Expression was classified as follows: 0: Very low or with no staining; 1: intensity just above background level; 2 : clearly visible at low magnification; and 3: strikingly visible at low magnification. Ki-67 labeling index (LI) was calculated as the percentage of tumor cells that were stained. All immunohistochemical analyses were evaluated by two experienced pathologists who were unaware of the patients' clinical condition.

Statistical analysis. The associations between EPHA2 expression and clinicopathological characteristics, such as: i) age at diagnosis, ii) serum PSA level at diagnosis, iii) D'Amico risk stratification, iv) GS at prostatectomy, v) pathological T-stage, vi) lymphatic invasion, vii) peripheral nerve invasion, and viii) BCR, were examined using the chi-square test or Fisher's exact test. Cancer survival analysis was performed using the Kaplan-Meier method, log-rank test, and Cox's proportional hazards model. The threshold for statistical significance was set at $p<0.05$. BCR was defined as an increase in PSA level of $>0.2 \mathrm{ng} / \mathrm{ml}$ after two different measurements at least 3 months apart. Finally, because cell proliferation and cell adhesion affect the relationship between EPHA2 expression and prognosis, Spearman rank correlation testing was used to investigate the correlations between Ki-67 LI, E-cadherin, and EPHA2. The statistical software used was JMP ${ }^{\circledR}$ Pro 13 (SAS Institute Inc., Cary, NC, USA).

\section{Results}

Patient characteristics. The median postoperative follow-up period was 60 months. The median age was 67 years, and the median PSA level at initial diagnosis was $7.90 \mathrm{ng} / \mathrm{ml}$. GS at prostatectomy were less than or equal to 6 in 27 patients, equal to $7(3+4)$ in 103 patients, equal to $7(4+3)$ in 75 patients, and greater than or equal to 8 in 36 patients. Pathological stages were T2a or T2b in 37 patients, T2c in 139 patients, and T3 in 65 patients. Additionally, the number of patients with positive resection margins was $122(50.6 \%)$. Overall, 120 patients (49.8\%) experienced BCR (Table I).

Immunohistochemical analysis of EPHA2 expression. Immunohistochemical classification of EPHA2 expression score was 0 in 18 patients $(7.5 \%), 1$ in $103(42.7 \%), 2$ in 88 (36.5\%), and 3 in $32(13.3 \%)$. To produce objective data, quantitative analysis of EPHA2 expression was performed using open-source NIH ImageJ software, as described previously $(28,29)$. A significant correlation was observed 

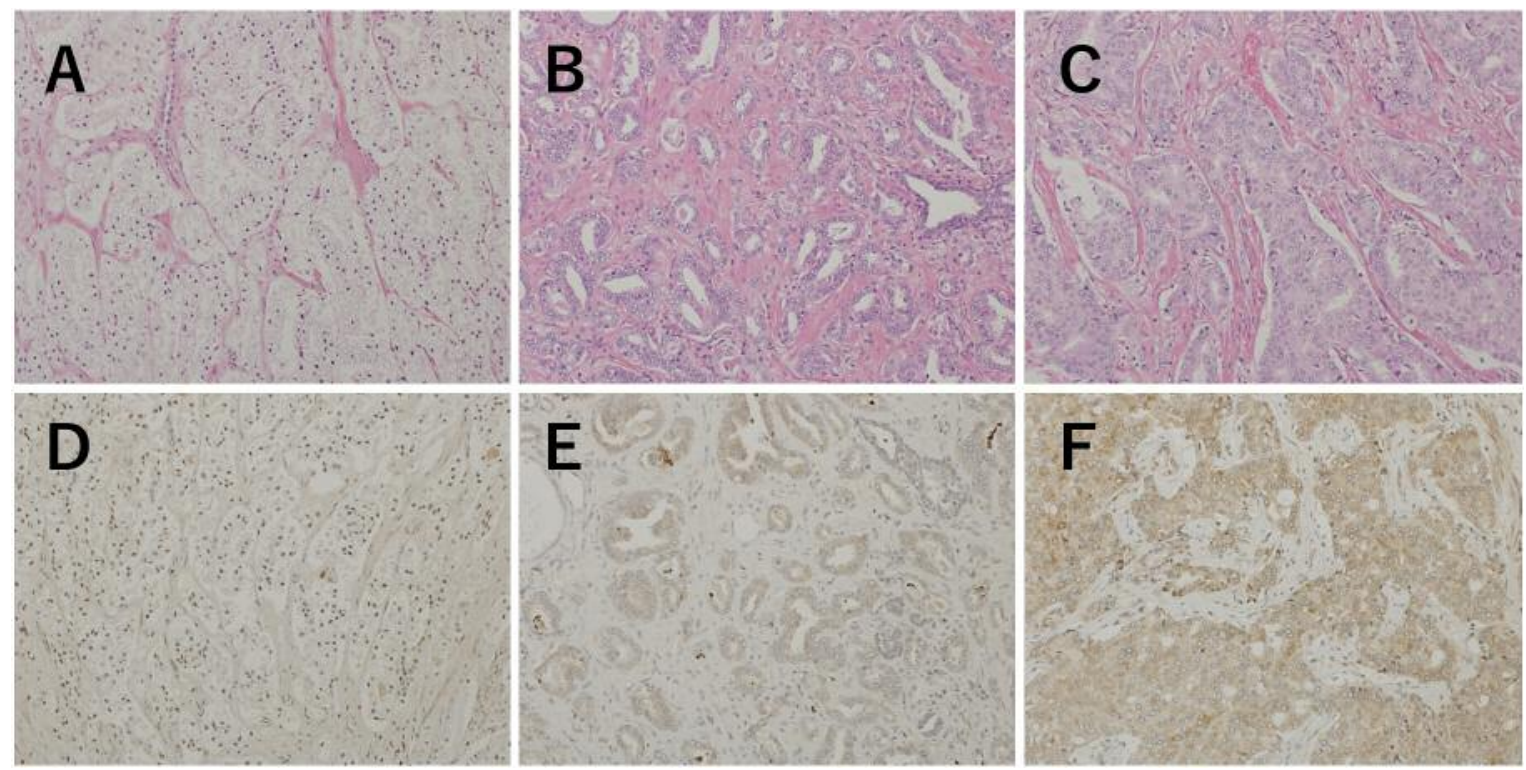

Figure 1. Erythropoietin-producing hepatocellular receptor A2 (EPHA2) expression in prostatic cancer. Photomicrographs of prostatic carcinoma cells stained with hematoxylin-eosin $(A-C)$, or immunostained for EPHA2 (D-F). EPHA2 expression can be seen in the cytoplasm. Expression was classified as 1 when the staining intensity was just above background level (D), 2 when clearly visible at a low magnification (E) and 3 when striking at a low magnification $(F)($ all $\times 200)$.
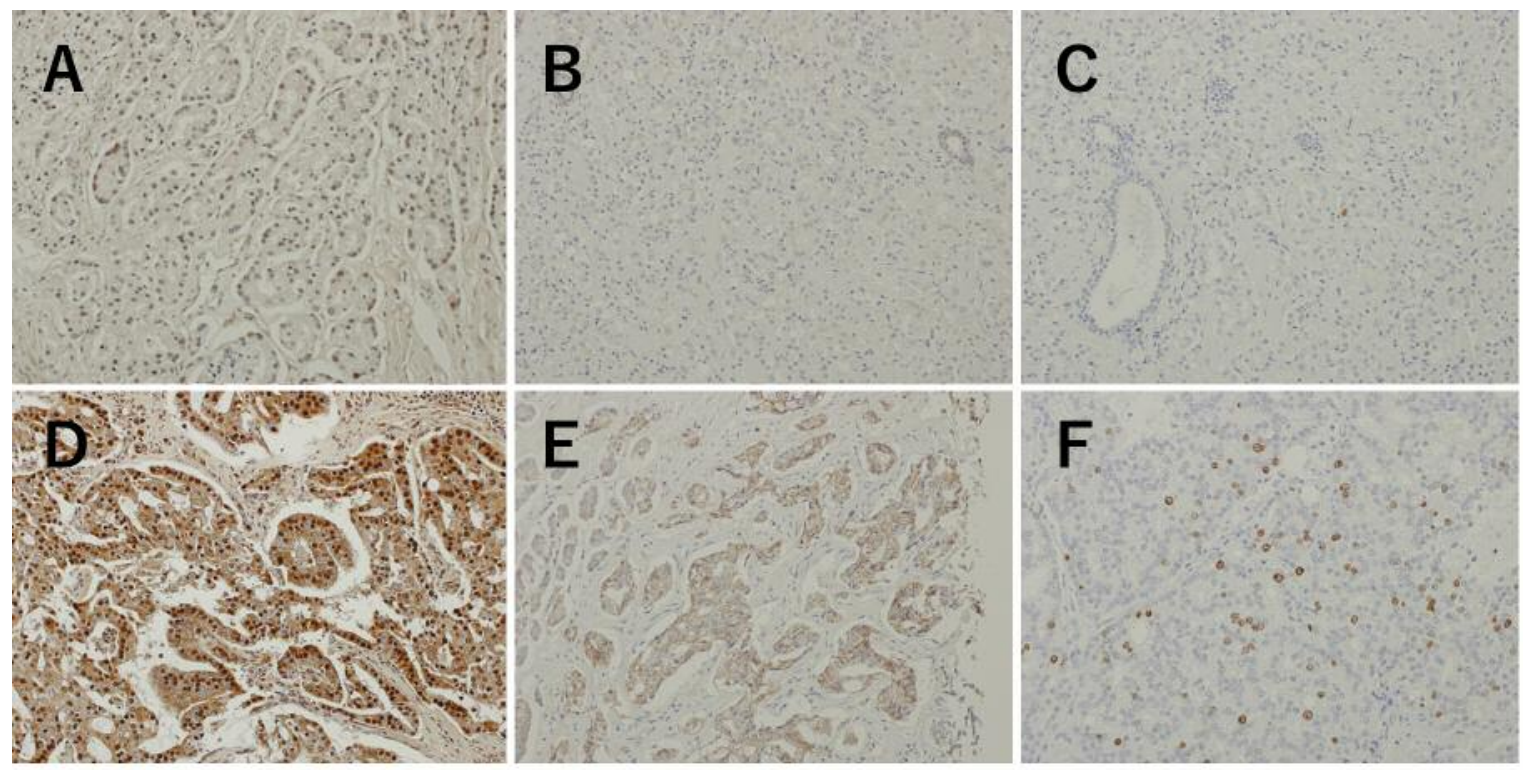

Figure 2. Examples of low (upper panel) and high (lower panel) expression of LMW-PTP (A, D), E-cadherin (B, E) and Ki-67 LI (C, F) in prostatic cancer tissue $($ all $\times 200)$.

between the evaluation using image analysis software and that performed by a pathologist applying the Wilcoxon ranksum test $(p<0.0001$; data not shown). By constructing a receiver operating characteristic curve, EPHA2 expression was categorized as high $(\geq 2)$ or low $(\leq 1)$. Of the 241 patients, $120(49.8 \%)$ were categorized in the highexpression group, and $121(50.2 \%)$ were categorized into the low-expression group. 
Table I. Patient characteristics.

\begin{tabular}{|c|c|}
\hline Parameter & Value \\
\hline Patients, n (\%). & 241 \\
\hline \multicolumn{2}{|c|}{ Age at diagnosis, years } \\
\hline Median (range) & $67(50-77)$ \\
\hline \multicolumn{2}{|c|}{ PSA level at diagnosis, $\mathrm{ng} / \mathrm{ml}$} \\
\hline Median (range) & $7.90(2.13-62.34)$ \\
\hline$<10$ & $163(67.6 \%)$ \\
\hline$>10$ & $78(32.4 \%)$ \\
\hline \multicolumn{2}{|c|}{ D'Amico risk stratification, $\mathrm{n}(\%)$} \\
\hline Low & $43(17.8 \%)$ \\
\hline Intermediate & $113(46.9 \%)$ \\
\hline High & $85(35.3 \%)$ \\
\hline \multicolumn{2}{|c|}{ Gleason score, $\mathrm{n}(\%)$} \\
\hline$\leq 6$ & $27(11.2 \%)$ \\
\hline $3+4=7$ & $103(42.8 \%)$ \\
\hline $4+3=7$ & $75(31.1 \%)$ \\
\hline$\geq 8$ & $36(14.9 \%)$ \\
\hline \multicolumn{2}{|c|}{ Pathological T-stage, n (\%) } \\
\hline $\mathrm{T} 2 \mathrm{a}, \mathrm{b}$ & $37(15.3 \%)$ \\
\hline $\mathrm{T} 2 \mathrm{c}$ & $139(57.7 \%)$ \\
\hline $\mathrm{T} 3$ & $65(27.0 \%)$ \\
\hline \multicolumn{2}{|c|}{ Lymphatic invasion, $\mathrm{n}(\%)$} \\
\hline Yes & $12(5.0 \%)$ \\
\hline \multicolumn{2}{|c|}{ Peripheral nerve invasion, $\mathrm{n}(\%)$} \\
\hline Yes & $111(46.1 \%)$ \\
\hline \multicolumn{2}{|c|}{ Resection margin, n (\%) } \\
\hline Positive & $122(50.6 \%)$ \\
\hline \multicolumn{2}{|l|}{ Ki-67 LI, n (\%) } \\
\hline$<1 \%$ & $168(69.7 \%)$ \\
\hline $1-5 \%$ & $57(23.7 \%)$ \\
\hline$>5 \%$ & $16(6.6 \%)$ \\
\hline \multicolumn{2}{|c|}{ Follow-up time, months } \\
\hline Median (IQR) & $72(48-84)$ \\
\hline \multicolumn{2}{|c|}{ Biochemical recurrence, $\mathrm{n}(\%)$} \\
\hline Yes & $120(49.8 \%)$ \\
\hline No & $121(50.2 \%)$ \\
\hline
\end{tabular}

IQR: Interquartile range; LI: labeling index; PSA: prostate-specific antigen.

The correlations between EPHA2 expression and clinicopathological characteristics are summarized in Table II. Higher GS $(p=0.022)$, high Ki-67 LI $(p=0.0002)$ and BCR $(p<0.0001)$ were more frequently identified in the high-expression group than in the low-expression group. In addition, EPHA2 was overexpressed in three out of the four men who presented with local recurrence. Furthermore, all three who died of PCa showed overexpression of EPHA2 (data not shown because of the small sample size).

Identification of EPHA2 as a biomarker of prostatic BCR. Kaplan-Meier curves demonstrated that the time to BCR was significantly shorter in patients with high EPHA2 expression than in those with low EPHA2 expression $(p<0.0001$; Figure $3)$. Univariate and multivariate analyses of EPHA2

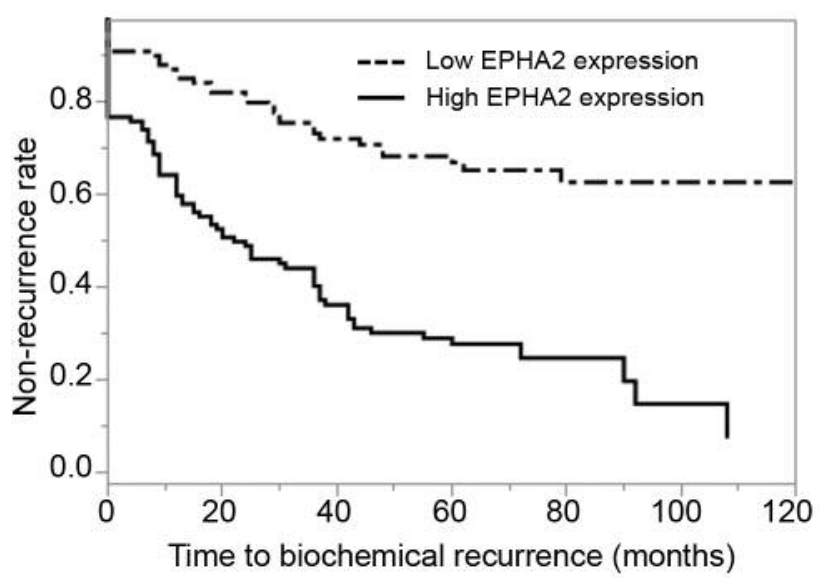

Figure 3. Relationship between erythropoietin-producing hepatocellular receptor A2 (EPHA2) expression and time to biological recurrence. Time to biochemical recurrence was significantly shorter in patients with high EPHA2 expression than in those with low EPHA2 expression $(p<0.0001$, Kaplan-Meier analysis $)$.

expression are shown in Table III. Univariate analysis for time to BCR revealed that EPHA2 expression $(p<0.0001)$, $>10 \mathrm{ng} / \mathrm{ml}$ PSA at diagnosis $(p=0.0022)$, GS $>6(p=0.0043)$, $>\mathrm{T} 2 \mathrm{~b}$ pathological T-stage $(p<0.0001)$, peripheral nerve invasion $(p=0.0039)$, positive resection margin $(p<0.0001)$ and Ki-67 LI $(p=0.0171)$ were significant predictors for BCR. Moreover, multivariate analysis demonstrated that there were no relationships between BCR and GS or pathological $\mathrm{T}$ stage. In contrast, EPHA2 expression level $(p<0.0001)$, PSA level at diagnosis $(p=0.0112)$, resection margin positive $(p=0.0015)$, and $\mathrm{Ki}-67 \mathrm{LI}>1 \%(p=0.0251)$ were identified as independent poor prognostic factors for BCR.

Correlation between EPHA2 expression and expression of LMWPTP, E-cadherin and Ki-67 in PCa. A positive correlation was detected between EPHA2 and both LMW-PTP and Ki-67 LI (Spearman's ranked correlation coefficients: 0.521, $p<0.0001$ and $0.483, p<0.0001$, respectively). A negative correlation was detected between EPHA2 and E-cadherin (Spearman's ranked correlation coefficient: $-0.585, p<0.0001$ ).

\section{Discussion}

BCR serves as an indicator of the early stage of relapse for patients with $\mathrm{PCa}(30,31)$. Some studies have attempted to investigate prognostic factors for BCR following radical prostatectomy (32-34). This study is the first to evaluate the feasibility of EPHA2 overexpression as a predictive factor for BCR, and to assess correlations between EPHA2, LMWPTP, and E-cadherin levels in PCa. In our study, patients in 
Table II. Patient characteristics and association between erythropoietin-producing hepatocellular receptor A2 (EPHA2) expression and clinicopathological characteristics.

\begin{tabular}{|c|c|c|c|}
\hline \multirow[b]{2}{*}{ Parameter } & \multicolumn{2}{|c|}{ EPHA2 expression } & \multirow[b]{2}{*}{$p$-Value } \\
\hline & Low & High & \\
\hline Patients; no. & $121(50.2 \%)$ & $120(49.8 \%)$ & \\
\hline \multicolumn{4}{|c|}{ Follow-up time, months } \\
\hline Median (IQR) & $72(36-84)$ & $72(60-84)$ & 0.135 \\
\hline \multicolumn{4}{|c|}{ Age at diagnosis, years } \\
\hline Median (range) & $67(54-75)$ & $67(50-77)$ & 0.856 \\
\hline \multicolumn{4}{|c|}{ PSA level at diagnosis, $\mathrm{ng} / \mathrm{ml}$} \\
\hline Median (range) & $8.65(3.68-50.5)$ & $7.46(2.13-62.34)$ & 0.732 \\
\hline$<10$ & $77(63.6 \%)$ & $86(71.7 \%)$ & 0.182 \\
\hline$>10$ & $44(36.4 \%)$ & $34(28.3 \%)$ & - \\
\hline \multicolumn{4}{|l|}{ Gleason score } \\
\hline$\leq 6$ & $19(15.7 \%)$ & $8(6.7 \%)$ & 0.022 \\
\hline $3+4=7$ & $49(40.5 \%)$ & $54(45.0 \%)$ & - \\
\hline $4+3=7$ & $41(33.9 \%)$ & $34(28.3 \%)$ & - \\
\hline$\geq 8$ & $12(9.9 \%)$ & $24(20.0 \%)$ & - \\
\hline \multicolumn{4}{|c|}{ Pathological T-stage, n (\%) } \\
\hline $\mathrm{T} 2 \mathrm{a}, \mathrm{b}$ & $17(14.1 \%)$ & $20(16.6 \%)$ & 0.154 \\
\hline $\mathrm{T} 2 \mathrm{c}$ & $77(63.6 \%)$ & $62(51.7 \%)$ & - \\
\hline $\mathrm{T} 3$ & $27(22.3 \%)$ & $38(31.7 \%)$ & - \\
\hline \multicolumn{4}{|c|}{ Lymphatic invasion, $\mathrm{n}(\%)$} \\
\hline Yes & $5(4.1 \%)$ & $7(5.8 \%)$ & 0.543 \\
\hline \multicolumn{4}{|c|}{ Peripheral nerve invasion, $\mathrm{n}(\%)$} \\
\hline Yes & $50(41.3 \%)$ & $61(50.8 \%)$ & 0.138 \\
\hline \multicolumn{4}{|c|}{ Resection margin, $\mathrm{n}(\%)$} \\
\hline Positive & $58(47.9 \%)$ & $64(53.3 \%)$ & 0.402 \\
\hline \multicolumn{4}{|l|}{ Ki-67 LI, n (\%) } \\
\hline$<1 \%$ & $94(77.7 \%)$ & $74(61.7 \%)$ & 0.0002 \\
\hline $1-5 \%$ & $26(21.5 \%)$ & $31(25.8 \%)$ & - \\
\hline$>5 \%$ & $1(0.8 \%)$ & $15(12.5 \%)$ & - \\
\hline \multicolumn{4}{|c|}{ Biochemical recurrence, n (\%) } \\
\hline Yes & $35(28.9 \%)$ & $85(70.8 \%)$ & $<0.0001$ \\
\hline No & $86(71.1 \%)$ & $35(29.2 \%)$ & - \\
\hline
\end{tabular}

IQR: Interquartile range; LI: labeling index; PSA: prostate-specific antigen.

the high EPHA2 expression group exhibited a poor prognosis compared with those in the low-expression group, and the results of univariate and multivariate analyses also suggested that high EPHA2 expression may be a useful prognostic factor for BCR. In addition, this study demonstrated positive correlation between EPHA2 and LMW-PTP, and negative correlation between EPHA2 and E-cadherin.

$\mathrm{PCa}$, which is typical of a cancer with a high degree of heterogeneity, both suppresses and stimulates the functions of multiple signal transduction pathways to varying degrees, with the final output of these processes giving $\mathrm{PCa}$ its characteristics. One group of such products of signal transduction, PTKs, are known to have functional and expression-related abnormalities in many malignancies. For example, some findings suggest that the increased phosphorylation of human epidermal growth factor receptor type 2 (HER2) in cases of PCa is closely related to androgen- independent proliferation (35-37). However, there are many unclear points about the role of PTKs in relation to PCa.

EPHA2 is a member of the EPH family of RTKs; its high expression has been reported in various cancer types, including melanoma, and breast $(20,38)$, colon (39), esophageal cancer (40), lung (41), and ovarian (42) cancer. High levels of EPHA2 protein expression were correlated with aggressive cancer behavior and poor prognosis $(43,44)$. EPHA2 was found to be overexpressed in $\mathrm{PCa}$ relative to expression levels in normal tissue (45). In addition, the expression levels of EPHA2 and PI3K were positively correlated with vasculogenic mimicry both in vivo and in vitro (46). However, few reports have evaluated the correlation of EPHA2 with BCR using surgically obtained specimens. Therefore, in this study, we evaluated the expression of EPHA2 in PCa using surgically obtained specimens from 241 patients. Based on these findings, we consider histological 
Table III. Univariate and multivariate analyses of time to biochemical recurrence.

\begin{tabular}{|c|c|c|c|c|}
\hline \multirow[b]{2}{*}{ Parameter } & \multicolumn{2}{|c|}{ Univariate } & \multicolumn{2}{|c|}{ Multivariate } \\
\hline & HR $(95 \% \mathrm{CI})$ & $p$-Value & HR $(95 \% \mathrm{CI})$ & $p$-Value \\
\hline Age at diagnosis, $>67$ Years & $1.07(0.75-1.53)$ & 0.715 & & \\
\hline PSA level at diagnosis, $>10 \mathrm{ng} / \mathrm{ml}$ & $1.80(1.24-2.59)$ & 0.0022 & $1.72(1.13-2.62)$ & 0.0112 \\
\hline Gleason score & & 0.0043 & & 0.645 \\
\hline$\leq 6$ & 1 & - & 1 & - \\
\hline $3+4=7$ & $1.73(0.87-3.96)$ & 0.126 & $1.10(0.53-2.56)$ & 0.897 \\
\hline $4+3=7$ & $2.09(1.03-4.82)$ & 0.0413 & $1.20(0.57-2.89)$ & 0.627 \\
\hline$\geq 8$ & $3.62(1.70-8.62)$ & 0.0006 & $1.54(0.67-3.89)$ & 0.495 \\
\hline Pathological T stage & & $<0.0001$ & & 0.078 \\
\hline $\mathrm{T} 2 \mathrm{a}, \mathrm{b}$ & 1 & - & 1 & - \\
\hline $\mathrm{T} 2 \mathrm{c}$ & $1.15(0.67-2.12)$ & 0.608 & $1.40(0.80-2.62)$ & 0.293 \\
\hline $\mathrm{T} 3$ & $2.96(1.68-5.51)$ & 0.0001 & $2.01(1.08-3.93)$ & 0.035 \\
\hline \multicolumn{5}{|l|}{ Lymphatic invasion } \\
\hline Yes & $2.20(1.03-4.12)$ & 0.056 & & \\
\hline \multicolumn{5}{|l|}{ Peripheral nerve invasion } \\
\hline Yes & $1.70(1.19-2.45)$ & 0.0039 & $1.05(0.70-1.60)$ & 0.792 \\
\hline \multicolumn{5}{|l|}{ Resection margin } \\
\hline Positive & $2.23(1.55-3.27)$ & $<0.0001$ & $1.92(1.28-2.89)$ & 0.0015 \\
\hline Ki-67 LI & & 0.0171 & & 0.0251 \\
\hline$<1 \%$ & 1 & - & 1 & - \\
\hline $1-5 \%$ & $1.35(0.87-2.18)$ & 0.181 & $1.86(1.18-3.04)$ & 0.004 \\
\hline$>5 \%$ & $2.20(1.14-3.90)$ & 0.021 & $1.22(0.64-2.52)$ & 0.37 \\
\hline \multicolumn{5}{|l|}{ Expression of EPHA2 } \\
\hline High & $3.23(2.19-4.87)$ & $<0.0001$ & $3.62(2.39-5.61)$ & $<0.0001$ \\
\hline
\end{tabular}

CI: Confidence interval; EPHA2: erythropoietin-producing hepatocellular receptor A2; HR: hazard ratio; LI: labeling index; PSA: prostate-specific antigen.

evaluation of EPHA2 to be useful for decision-making regarding the postoperative treatment strategy.

In malignant cells, hyperexpressed EPHA2 has higher enzyme activity when in its dephosphorylated state than in its phosphorylated state $(20,47)$. It has been reported that when in its dephosphorylated state, hyperexpressed EPHA2 regulates tumor cell proliferation, migration, infiltration, and other behaviors, and that in a large number of cancer types, it positively regulates tumor growth $(48,49)$. LMW-PTP, an $18 \mathrm{kDa}$ protein tyrosine phosphatase, is an important negative regulator of EPHA2 phosphorylation, and therefore it is involved in the proliferation, invasion, and migration of tumors through the dephosphorylation of EPHA2 (23). p190 RHO family GTPase-activating protein (RhoGAP), a protein involved in the regulation of cytoskeleton rearrangement, is also regulated by LMW-PTP, with consequent effects on RhoA (50). Fang et al. describe that the overexpression of EPHA2 promotes destabilization of the adherens junction through the LMW-PTP-p190RhoGAP-RhoA axis (51). Indeed, some reports show that the expression of EPHA2 is inversely correlated with that of E-cadherin in some types of cancer, including gastric (52) and colorectal (52, 53). However, the exact association between EPHA2 and E- cadherin in PCa is unclear. Here, high EPHA2 expression strongly was correlated with high LMW-PTP expression. In addition, we found negative correlation between EPHA2 and E-cadherin in patients with PCa. Therefore, we believe that EPHA2 may act as a positive regulator of PCa growth, destabilizing cell-to-cell adherence, when it becomes dephosphorylated by the action of LMW-PTP. Furthermore, the Ki-67 LI, a recognized cell proliferation marker, was significantly higher in the group with high expression of EPHA2 than in the low-expression group. These findings indicate that not only cell-to-cell adhesion but also cell proliferation may be induced as a result of the dephosphorylation of EPHA2 in PCa.

Because of the prevalence of EPHA2 overexpression in many kinds of cancer, EPHA2 has been found to have an integral role in cancer formation, and is expected to be a good target for antibody and small conjugate-based theranostic agent (54). There are some reports of several monoclonal antibodies that are specific for human EPHA2 (55). However, the potential application of these approaches for the treatment of $\mathrm{PCa}$ is not known, and is the subject of our current and future research. A technique to measure serum EPHA2 concentration using enzyme-linked immunosorbent assay has been developed. 
Serum EPHA2 was higher in patients with PCa than in patients with healthy prostates or with prostatic hyperplasia.

Because EPHA2 expression in resected specimens was a strong predictor of BCR in our study, the EPHA2 expression level may provide useful information for determining postoperative treatment strategy. The value of EPHA2 expression as a predictive biomarker may be limited, however, if there is insufficient biopsy tissue to be assessed, and because of the heterogeneity of PCa. For this reason, our future aim is to measure EPHA2 expression in different size prostate biopsy tissues, and to include this assessment in the initial diagnostic tests, in order to better explore the clinical applications of this biomarker. As the function of EPHA2 in PCa becomes gradually clear, we expect that assessment of EPHA2 will be applied in the diagnosis and treatment of PCa.

\section{Conclusion}

High EPHA2 expression in radical prostatectomy specimens is useful as predictive biomarker of BCR. EPHA2 has the potential to be a highly useful prognostic biomarker, in conjunction with existing markers (GS, pathological T-stage, resection margin status and PSA level), and to be a key therapeutic target in human $\mathrm{PCa}$.

\section{Conflicts of Interest}

All Authors have declared no conflicts of interest exist in regard to this study.

\section{Authors' Contributions}

Hirofumi Kurose and Kosuke Ueda designed the study, and wrote the initial draft of the article. Reiichiro Kondo contributed to analysis and interpretation of data, and assisted in the preparation of the article. Tatsuyuki Kakuma contributed to statistics analysis. All other Authors have contributed to data collection and interpretation, and critically reviewed the article. All Authors approved the final version of the article, and agree to be accountable for all aspects of the work in ensuring that questions related to the accuracy or integrity of any part of the work are appropriately investigated and resolved.

\section{References}

1 Nichol AM, Warde P and Bristow RG: Optimal treatment of intermediate-risk prostate carcinoma with radiotherapy: Clinical and translational issues. Cancer 104: 891-905, 2005. PMID: 16007687. DOI: $10.1002 / \mathrm{cncr} .21257$

2 Lowrance WT, Eastham JA, Savage C, Maschino AC, Laudone VP, Dechet CB, Stephenson RA, Scardino PT and Sandhu JS: Contemporary open and robotic radical prostatectomy practice patterns among urologists in the United States. J Urol 187: 20872092, 2012. PMID: 22498227. DOI: 10.1016/j.juro.2012.01.061

3 Hull GW, Rabbani F, Abbas F, Wheeler TM, Kattan MW and Scardino PT: Cancer control with radical prostatectomy alone in
1,000 consecutive patients. J Urol 167: 528-534, 2002. PMID: 11792912.

4 D'Amico AV, Whittington R, Malkowicz SB, Schultz D, Blank K, Broderick GA, Tomaszewski JE, Renshaw AA, Kaplan I, Beard CJ and Wein A: Biochemical outcome after radical prostatectomy, external beam radiation therapy, or interstitial radiation therapy for clinically localized prostate cancer. JAMA 280: 969-974, 1998. PMID: 9749478.

5 D'Amico AV, Chen MH, Roehl KA and Catalona WJ: Preoperative PSA velocity and the risk of death from prostate cancer after radical prostatectomy. N Engl J Med 351: 125-135, 2004. PMID: 15247353. DOI: 10.1056/NEJMoa032975

6 Horiguchi A, Nakashima J, Horiguchi Y, Nakagawa K, Oya M, Ohigashi $\mathrm{T}$, Marumo $\mathrm{K}$ and Murai $\mathrm{M}$ : Prediction of extraprostatic cancer by prostate specific antigen density, endorectal MRI, and biopsy Gleason score in clinically localized prostate cancer. Prostate 56: 23-29, 2003. PMID: 12746843. DOI: $10.1002 /$ pros. 10239

7 Ohori M, Kattan MW, Koh H, Maru N, Slawin KM, Shariat S, Muramoto M, Reuter VE, Wheeler TM and Scardino PT: Predicting the presence and side of extracapsular extension: A nomogram for staging prostate cancer. J Urol 171: 1844-1849; discussion 1849, 2004. PMID: 15076291. DOI: 10.1097/ 01.ju.0000121693.05077.3d

8 Stephenson AJ, Shariat SF, Zelefsky MJ, Kattan MW, Butler EB, Teh BS, Klein EA, Kupelian PA, Roehrborn CG, Pistenmaa DA, Pacholke HD, Liauw SL, Katz MS, Leibel SA, Scardino PT and Slawin KM: Salvage radiotherapy for recurrent prostate cancer after radical prostatectomy. JAMA 291: 1325-1332, 2004. PMID: 15026399. DOI: 10.1001/jama.291.11.1325

9 Swindle P, Eastham JA, Ohori M, Kattan MW, Wheeler T, Maru $\mathrm{N}$, Slawin $\mathrm{K}$ and Scardino PT: Do margins matter? The prognostic significance of positive surgical margins in radical prostatectomy specimens. J Urol 179: S47-51, 2008. PMID: 18405751. DOI: $10.1016 /$ j.juro.2008.03.137

10 Budaus L, Isbarn H, Eichelberg C, Lughezzani G, Sun M, Perrotte P, Chun FK, Salomon G, Steuber T, Kollermann J, Sauter G, Ahyai SA, Zacharias M, Fisch M, Schlomm T, Haese A, Heinzer $\mathrm{H}$, Huland $\mathrm{H}$, Montorsi F, Graefen $\mathrm{M}$ and Karakiewicz PI: Biochemical recurrence after radical prostatectomy: Multiplicative interaction between surgical margin status and pathological stage. J Urol 184: 1341-1346, 2010. PMID: 20723925. DOI: 10.1016/j.juro.2010.06.018

11 Yossepowitch O, Briganti A, Eastham JA, Epstein J, Graefen M, Montironi $\mathrm{R}$ and Touijer K: Positive surgical margins after radical prostatectomy: A systematic review and contemporary update. Eur Urol 65: 303-313, 2014. PMID: 23932439. DOI: 10.1016/j.eururo.2013.07.039

12 Negishi T, Kuroiwa K, Hori Y, Tomoda T, Uchino H, Tokuda N, Furubayashi N, Nagase K, Iwai $\mathrm{H}$ and Nakamura M: Predictive factors of late biochemical recurrence after radical prostatectomy. Jpn J Clin Oncol 47: 233-238, 2017. PMID: 27940489. DOI: $10.1093 /$ jjco/hyw181

13 Sinnberg T, Lasithiotakis K, Niessner H, Schittek B, Flaherty KT, Kulms D, Maczey E, Campos M, Gogel J, Garbe C and Meier F: Inhibition of PI3K-AKT-mTOR signaling sensitizes melanoma cells to cisplatin and temozolomide. J Invest Dermatol 129: 1500-1515, 2009. PMID: 19078992. DOI: $10.1038 /$ jid.2008.379 
14 Jiang X, Zhou J, Yuen NK, Corless CL, Heinrich MC, Fletcher JA, Demetri GD, Widlund HR, Fisher DE and Hodi FS: Imatinib targeting of KIT-mutant oncoprotein in melanoma. Clin Cancer Res 14: 7726-7732, 2008. PMID: 19047099. DOI: 10.1158/ 1078-0432.Ccr-08-1144

15 Lasithiotakis KG, Sinnberg TW, Schittek B, Flaherty KT, Kulms D, Maczey E, Garbe C and Meier FE: Combined inhibition of MAPK and mTOR signaling inhibits growth, induces cell death, and abrogates invasive growth of melanoma cells. J Invest Dermatol 128: 2013-2023, 2008. PMID: 18323781. DOI: 10.1038/jid.2008.44

16 Bellmunt J, Hussain M and Dinney CP: Novel approaches with targeted therapies in bladder cancer. Therapy of bladder cancer by blockade of the epidermal growth factor receptor family. Crit Rev Oncol Hematol 46 Suppl: S85-104, 2003. PMID: 12850530.

17 Sulman EP, Tang XX, Allen C, Biegel JA, Pleasure DE, Brodeur GM and Ikegaki N: ECK, a human EPH-related gene, maps to $1 \mathrm{p} 36.1$, a common region of alteration in human cancers. Genomics 40: 371-374, 1997. PMID: 9119409. DOI: 10.1006/ geno.1996.4569

18 Lindberg RA and Hunter T: cDNA cloning and characterization of ECK, an epithelial cell receptor protein-tyrosine kinase in the EPH/ELK family of protein kinases. Mol Cell Biol 10: 63166324, 1990. PMID: 2174105.

19 Chen P, Huang Y, Zhang B, Wang Q and Bai P: EPHA2 enhances the proliferation and invasion ability of $\mathrm{LNCaP}$ prostate cancer cells. Oncol Lett 8: 41-46, 2014. PMID: 24959216. DOI: $10.3892 / \mathrm{ol} .2014 .2093$

20 Zelinski DP, Zantek ND, Stewart JC, Irizarry AR and Kinch MS: EPHA2 overexpression causes tumorigenesis of mammary epithelial cells. Cancer Res 61: 2301-2306, 2001. PMID: 11280802.

21 Abraham S, Knapp DW, Cheng L, Snyder PW, Mittal SK, Bangari DS, Kinch M, Wu L, Dhariwal J and Mohammed SI: Expression of EPHA2 and ephrin A-1 in carcinoma of the urinary bladder. Clin Cancer Res 12: 353-360, 2006. PMID: 16428472. DOI: 10.1158/1078-0432.Ccr-05-1505.

22 Kurose H, Ueda K, Kondo R, Ogasawara S, Kusano H, Sanada S, Naito Y, Akiba J, Kakuma T, Igawa T and Yano H: Lowmolecular-weight protein tyrosine phosphatase is a possible biomarker for predicting postoperative biochemical recurrence in prostate cancer with negative surgical margins. Anticancer Res 39(2): 957-964, 2019. PMID: 30711981. DOI: 10.21873/ anticanres.13199

23 Souza AC, Azoubel S, Queiroz KC, Peppelenbosch MP and Ferreira CV: From immune response to cancer: A spot on the low molecular weight protein tyrosine phosphatase. Cell Mol Life Sci 66: 1140-1153, 2009. PMID: 19002379. DOI: 10.1007/ s00018-008-8501-8

24 Kinch MS and Carles-Kinch K: Overexpression and functional alterations of the EPHA2 tyrosine kinase in cancer. Clin Exp Metastasis 20: 59-68, 2003. PMID: 12650608.

25 Kikawa KD, Vidale DR, Van Etten RL and Kinch MS: Regulation of the EPHA2 kinase by the low molecular weight tyrosine phosphatase induces transformation. J Biol Chem 277: 39274-39279, 2002. PMID: 12167657. DOI: 10.1074/jbc. M207127200.

26 Zantek ND, Azimi M, Fedor-Chaiken M, Wang B, Brackenbury $\mathrm{R}$ and Kinch MS: E-Cadherin regulates the function of the EPHA2 receptor tyrosine kinase. Cell Growth Differ 10: 629638, 1999. PMID: 10511313.
27 Humphrey PA: WHO Classification of Tumors of the Prostate, 2016. Available from: https://handouts.uscap.org/2016_cm05_ humph_1.pdf

28 Helps SC, Thornton E, Kleinig TJ, Manavis J and Vink R: Automatic nonsubjective estimation of antigen content visualized by immunohistochemistry using color deconvolution. Appl Immunohistochem Mol Morphol 20: 82-90, 2012. PMID: 22157059. DOI: 10.1097/PAI.0b013e31821fc $8 \mathrm{~cd}$

29 Kurose H, Naito Y, Akiba J, Kondo R, Ogasawara S, Kusano H, Sanada S, Abe H, Kakuma T, Ueda K, Igawa T and Yano H: High sulfite oxidase expression could predict postoperative biochemical recurrence in patients with prostate cancer. Med Mol Morphol, 2019. PMID: 30631948. DOI: 10.1007/s00795-018-00214-1

30 Lattouf JB and Saad F: Digital rectal exam following prostatectomy: Is it still necessary with the use of PSA? Eur Urol 43: 333-336, 2003. PMID: 12667712.

31 Pound CR, Christens-Barry OW, Gurganus RT, Partin AW and Walsh PC: Digital rectal examination and imaging studies are unnecessary in men with undetectable prostate specific antigen following radical prostatectomy. J Urol 162: 1337-1340, 1999. PMID: 10492192.

32 Aoun F, Albisinni S, Henriet B, Tombal B, Van Velthoven R and Roumeguere T: Predictive factors associated with biochemical recurrence following radical prostatectomy for pathological T2 prostate cancer with negative surgical margins. Scand J Urol 51: 20-26, 2017. PMID: 27910728. DOI: 10.1080/21681805.2016. 1263237

33 Lee S, Jeong CW, Jeong SJ, Hong SK, Choi W, Byun SS and Lee SE: The prognostic value of pathologic prostate-specific antigen mass ratio in patients with localized prostate cancer with negative surgical resection margins. Urology 82: 865-869, 2013. PMID: 23830078. DOI: 10.1016/j.urology.2013.04.040

34 Cao D, Kibel AS, Gao F, Tao Y and Humphrey PA: The Gleason score of tumor at the margin in radical prostatectomy is predictive of biochemical recurrence. Am J Surg Pathol 34: 9941001, 2010. PMID: 20505501. DOI: 10.1097/PAS.0b013e31 $81 \mathrm{e} 103 \mathrm{bf}$

35 Andersson J, Rosestedt M and Orlova A: Imaging of HER2 may improve the outcome of external irradiation therapy for prostate cancer patients. Oncol Lett 9: 950-954, 2015. PMID: 25624915. DOI: $10.3892 / \mathrm{ol} .2014 .2760$

36 Muniyan S, Chen SJ, Lin FF, Wang Z, Mehta PP, Batra SK and Lin MF: ERBB-2 signaling plays a critical role in regulating androgen-sensitive and castration-resistant androgen receptorpositive prostate cancer cells. Cell Signal 27: 2261-2271, 2015. PMID: 26257301. DOI: 10.1016/j.cellsig.2015.08.002

37 Tobiume M, Yamada Y, Nakamura K, Aoki S, Zennami K, Kato Y, Nishikawa G, Yokoi T and Honda N: Significant prognostic factor of immunohistochemical HER-2 expression using initial prostate biopsy specimens with M1b prostate cancer. Prostate 71: 385-393, 2011. PMID: 20812221. DOI: 10.1002/pros.21252

38 Easty DJ and Bennett DC: Protein tyrosine kinases in malignant melanoma. Melanoma Res 10: 401-411, 2000. PMID: 11095400.

39 Rosenberg IM, Goke M, Kanai M, Reinecker HC and Podolsky DK: Epithelial cell kinase-B61: An autocrine loop modulating intestinal epithelial migration and barrier function. Am J Physiol 273: G824-832, 1997. PMID: 9357823.

40 Miyazaki T, Kato H, Fukuchi M, Nakajima M and Kuwano H: EPHA2 overexpression correlates with poor prognosis in 
esophageal squamous cell carcinoma. Int J Cancer 103: 657-663, 2003. PMID: 12494475 . DOI: 10.1002/ijc. 10860

41 Kinch MS, Moore MB and Harpole DH Jr.: Predictive value of the EPHA2 receptor tyrosine kinase in lung cancer recurrence and survival. Clin Cancer Res 9: 613-618, 2003. PMID: 12576426.

42 Thaker PH, Deavers M, Celestino J, Thornton A, Fletcher MS, Landen CN, Kinch MS, Kiener PA and Sood AK: EPHA2 expression is associated with aggressive features in ovarian carcinoma. Clin Cancer Res 10: 5145-5150, 2004. PMID: 15297418. DOI: 10.1158/1078-0432.Ccr-03-0589

43 Hess AR, Seftor EA, Gardner LM, Carles-Kinch K, Schneider GB, Seftor RE, Kinch MS and Hendrix MJ: Molecular regulation of tumor cell vasculogenic mimicry by tyrosine phosphorylation: Role of epithelial cell kinase (Eck/EphA2). Cancer Res 61: 3250-3255, 2001. PMID: 11309274.

$44 \mathrm{Lu} \mathrm{M}$, Miller KD, Gokmen-Polar Y, Jeng MH and Kinch MS: EPHA2 overexpression decreases estrogen dependence and tamoxifen sensitivity. Cancer Res 63: 3425-3429, 2003. PMID: 12810680

45 Walker-Daniels J, Coffman K, Azimi M, Rhim JS, Bostwick DG, Snyder P, Kerns BJ, Waters DJ and Kinch MS: Overexpression of the EPHA2 tyrosine kinase in prostate cancer. Prostate 41: 275-280, 1999. PMID: 10544301.

46 Wang H, Lin H, Pan J, Mo C, Zhang F, Huang B, Wang Z, Chen $X$, Zhuang J, Wang D and Qiu S: Vasculogenic mimicry in prostate cancer: The roles of EPHA2 and PI3K. J Cancer 7: 1114-1124, 2016. PMID: 27326255. DOI: 10.7150/jca.14120

47 Easty DJ, Guthrie BA, Maung K, Farr CJ, Lindberg RA, Toso RJ, Herlyn M and Bennett DC: Protein B61 as a new growth factor: Expression of B61 and up-regulation of its receptor epithelial cell kinase during melanoma progression. Cancer Res 55: 2528-2532, 1995. PMID: 7780963

48 Brantley-Sieders DM, Caughron J, Hicks D, Pozzi A, Ruiz JC and Chen J: EPHA2 Receptor tyrosine kinase regulates endothelial cell migration and vascular assembly through phosphoinositide 3kinase-mediated RAC1 GTPase activation. J Cell Sci 117: 2037 2049, 2004. PMID: 15054110. DOI: 10.1242/jcs.01061
49 Pasquale EB: EPH receptor signalling casts a wide net on cell behaviour. Nat Rev Mol Cell Biol 6: 462-475, 2005. PMID: 15928710. DOI: $10.1038 / \mathrm{nrm} 1662$

50 Alho I, Costa L, Bicho M and Coelho C: Low molecular weight protein tyrosine phosphatase isoforms regulate breast cancer cells migration through a RHOA dependent mechanism. PLoS One 8: e76307, 2013. PMID: 24086724. DOI: 10.1371/journal. pone. 0076307

51 Fang WB, Ireton RC, Zhuang G, Takahashi T, Reynolds A and Chen J: Overexpression of EPHA2 receptor destabilizes adherens junctions via a RHOA-dependent mechanism. J Cell Sci 121: 358-368, 2008. PMID: 18198190. DOI: 10.1242/ jcs.017145

52 Yuan W, Chen Z, Wu S, Ge J, Chang S, Wang X, Chen J and Chen Z: Expression of EPHA2 and E-cadherin in gastric cancer: Correlated with tumor progression and lymphogenous metastasis. Pathol Oncol Res 15: 473-478, 2009. PMID: 19048396. DOI: 10.1007/s12253-008-9132-y

53 Saito T, Masuda N, Miyazaki T, Kanoh K, Suzuki H, Shimura T, Asao T and Kuwano H: Expression of EPHA2 and E-cadherin in colorectal cancer: Correlation with cancer metastasis. Oncol Rep 11: 605-611, 2004. PMID: 14767510.

54 Goldgur Y, Susi P, Karelehto E, Sanmark H, Lamminmaki U, Oricchio E, Wendel HG, Nikolov DB and Himanen JP: Generation and characterization of a single-chain anti-EPHA2 antibody. Growth Factors 32: 214-222, 2014. PMID: 25494541. DOI: $10.3109 / 08977194.2014 .983225$

55 Sakamoto A, Kato K, Hasegawa T and Ikeda S: An agonistic antibody to EPHA2 exhibits antitumor effects on human melanoma cells. Anticancer Res 38: 3273-3282, 2018. PMID: 29848674. DOI: 10.21873 /anticanres.12592

Received August 31, 2019

Revised September 19, 2019 Accepted September 26, 2019 